\title{
REVIEW \\ Obesity and the risk and outcome of infection
}

\author{
R Huttunen ${ }^{1}$ and J Syrjänen ${ }^{2}$
}

The interactions between obesity and infectious diseases have recently received increasing recognition as emerging data have indicated an association between obesity and poor outcome in pandemic H1N1 influenza infection. Obesity is an established risk factor for surgical-site infections, nosocomial infections, periodontitis and skin infections. Several studies indicate that acute pancreatitis is more severe in the obese. Data are controversial and limited as regards the association between obesity and the risk and outcome of community-acquired infections such as pneumonia, bacteremia and sepsis and obesity and the course of HIV infection. As the cause-effect relationship between obesity and infection remains obscure in many infectious diseases, further studies are warranted. The consequences of obesity may have substantial effects on the global burden of infectious diseases.

International Journal of Obesity (2013) 37, 333-340; doi:10.1038/ijo.2012.62; published online 1 May 2012

Keywords: infection; outcome; the risk of; influenza; nosocomial; pneumonia

\section{INTRODUCTION}

The incidence of obesity has increased rapidly during recent decades. More than $30 \%$ of Americans are obese, as are more than a quarter of men and women in several European countries. ${ }^{1}$ According to the World Health Organization definition, a person is considered overweight if her/his body mass index (BMI) is $>25$, and obese if $\mathrm{BMI}$ is $\geqslant 30 .^{2} \mathrm{~A}$ recent study on the Framingham Cohort indicated that the number of years lived with obesity is directly associated with the risk of mortality. ${ }^{3}$

Emerging data indicate an association between obesity and infectious diseases. ${ }^{4}$ Although the mechanism underlying these findings is not well established, a number of potential factors may be involved (Table 1)..$^{5}$ Obesity may influence either the risk of getting an infection or the outcome of an infection once it is established. Obesity-related immune system dysregulation, decreased cell-mediated immune responses, obesity-related comorbidities, respiratory dysfunction and pharmacological issues have been proposed as possible mechanisms. ${ }^{4,6}$ In the absence of sufficient scientific evidence, no dosing guidelines of antimicrobials for obesity have been published, although such would be eagerly awaited. ${ }^{\text {? }}$

The evidence would appear more substantial regarding the association between nosocomial as opposed to communityacquired infections, except for the recent findings in influenza pandemics. This may be due to the fact that the BMI is recorded routinely only in patients undergoing invasive and surgical procedures, which enables study of this association retrospectively, whereas the BMI is not usually recorded in hospital/health care admissions for other reasons or in the case of communityacquired infections. ${ }^{4}$ This may cause bias when evaluating the potential impact of obesity in community-acquired as compared with nosocomial infections.

Studies on the interactions between obesity and infection have used heterogeneous materials and the reporting of methods how BMI data were obtained are variable. Obesity is associated with multiple comorbidities such as type 2 diabetes and hypertension, which may contribute to outcomes. ${ }^{8}$ These factors may cause considerable variation between different studies in this field and the composition of multivariate models vary. Large epidemiological studies have studied the potential association between obesity and increased pneumonia risk showing controversial results. ${ }^{8-10}$ Kornum and associates documented that adjustment for major chronic diseases eliminated the association between obesity and pneumonia risk documented in an univariate model in one large epidemiological study. ${ }^{8}$ One possible bias in pneumonia studies is a misclassification bias due to difficulties in interpreting X-ray photographs of overweight persons. ${ }^{11}$ BMI data may be obtained by objective measurement on hospital admission or by inquiry of patient or closest relative. An important factor contributing to our knowledge on the convergence of obesity and infection is that excpecially the earliest studies in this field have used variable BMI cut offs to define obesity. ${ }^{12,13}$

The present article has its emphasis on reviewing current knowledge regarding the association between obesity and the risk and outcome of several infectious diseases. Areas with limited or controversial data are summarized in Table 2. The findings here would indicate that the association between obesity and infections has not been comprehensively established in a wide range of infectious diseases.

\section{THE MECHANISMS OF OBESITY IN INFECTIOUS DISEASES}

Obesity has been shown to have substantial effects on immune surveillance. ${ }^{14}$ Immune system cells and adipocytes evince similarities in structure and function such as the production of various inflammatory mediators. ${ }^{14,15}$ Adipose tissue mediates immune system and adipose tissue interactions by the secretion of adipokines, for example, leptin. ${ }^{15}$ The differentiation of macrophages has been shown to be affected by the presence of obesity

\footnotetext{
${ }^{1}$ University of Tampere Medical School, University of Tampere, Tampere, Finland and ${ }^{2}$ Department of Internal Medicine, Tampere University Hospital, Tampere, Finland. Correspondence: Dr R Huttunen, Department of Internal Medicine, Tampere University Hospital, Box 2000, Fl-33521 Tampere, Finland.

E-mail: reetta.huttunen@uta.fi

or Dr J Syrjänen, Department of Internal Medicine, Tampere University Hospital, FI-33521 Tampere, Finland.

E-mail: jaana.syrjanen@pshp.fi
}

Received 12 August 2011; revised 19 March 2012; accepted 20 March 2012; published online 1 May 2012 
Table 1. Obesity-related factors affecting the risk and outcome of infectious diseases

Obesity

Respiratory tract ${ }^{22}$

Pulmonary restriction

Decreased pulmonary volumes

Ventilation-perfusion mismatching

Obstructive sleep apnea

Risk of pulmonary embolism

Dysregulated immune response in the lung

Skin and soft tissues and bone $e^{23}$

Disrupted micro- and macrocirculation

Decreased wound healing

Lymphedema ${ }^{93}$

Immune system ${ }^{14}$

Impaired chemotaxis

Altered differentiation of macrophages

Dysregulated cytokine production

Imbalanced cross-talk between immune system and adipose cells

Obesity-related comorbidities

Diabetes mellitus

Atherosclerosis

Pharmacological issues ${ }^{7}$

Limited or no data on the right dosing of antimicrobials in obesity Altered protein binding, metabolism and volume of distribution of antimicrobials

Table 2. Infections, the risk or outcome of which have not been associated with obesity or infections on which the data are controversial

\begin{tabular}{|c|c|}
\hline \multicolumn{2}{|c|}{ No data/controversial or limited data } \\
\hline Infection risk & Infection outcome \\
\hline Pneumonia ${ }^{8-11}$ & Pneumonia ${ }^{6,115-121}$ \\
\hline $\begin{array}{l}\text { Helicobacter pylori } \\
\text { infection }^{122-127}\end{array}$ & $\begin{array}{l}\text { Helicobacter pylori infection } \\
\text { (no studies) }\end{array}$ \\
\hline $\begin{array}{l}\text { Fungal infections } \\
\text { (no studies) }\end{array}$ & $\begin{array}{l}\text { Nosocomial and surgical-site } \\
\text { infections } s^{86,87}\end{array}$ \\
\hline $\begin{array}{l}\text { Tropical infections } \\
\text { (no studies) }\end{array}$ & Periodontitis (no studies) \\
\hline Tuberculosis ${ }^{128-130}$ & Urinary tract infections (no studies) \\
\hline Influenza (no studies) & Skin infections ${ }^{99}$ \\
\hline Viral hepatitis (no studies) & Influenza viruses other than $\mathrm{H} 1 \mathrm{~N} 1^{\text {(ref. 37) }}$ \\
\hline $\begin{array}{l}\text { Bacteremia and } \\
\text { sepsis }^{43,57,58,65,74,87,131}\end{array}$ & Bacteremia and sepsis. $^{44,132}$ \\
\hline $\begin{array}{l}\text { HIV (no studies) } \\
\text { Acute pancreatitis }\end{array}$ & $\mathrm{HIV}^{133-140}$ \\
\hline
\end{tabular}

and complex interactions take place between immune cells and metabolic cells. ${ }^{15}$ Obesity violates the well-balanced system of adipocytes and immune cells, with subsequent disturbance to the immune surveillance system. This leads to dysregulated immune response, impaired chemotaxis and altered macrophage differentiation (Figure 1). ${ }^{14,15}$

The adipocyte derived cytokine leptin is a link between inflammation and metabolic alterations. Circulating leptin levels have been shown to reflect adipose tissue mass and nutritional status in noncritically ill individuals. ${ }^{16}$ Serum adiponectin, which also originates from adipose tissue, has been shown to predict mortality in critically ill patients upon admission to the intensive care unit (ICU). ${ }^{17}$ Obesity has been shown to be strongly associated with circulating levels of C-reactive protein and fibrinogen, and chronic inflammation has been considered to be one pathophysiological mechanism explaining the increased risk of atherosclerotic disease associated with obesity. ${ }^{18}$

Although obesity involves a risk of complications, prolonged hospitalization and need for mechanical ventilation following major trauma, ${ }^{19}$ the development of acute respiratory distress syndrome $\mathrm{e}^{20}$ and constitutes a risk factor for prolonged hospitalization associated with critical illness, ${ }^{21}$ the impact of obesity on intensive care-related mortality is controversial. ${ }^{21}$ Obesity has been shown to have an effect on pulmonary function ${ }^{22}$ and wound healing. ${ }^{23}$ It is somewhat surprising, how little is known as to the appropriate dosing of antimicrobials in obesity and there are no antimicrobial treatment guidelines for the obese. ${ }^{4,7}$

\section{INFLUENZA}

Interest in the interactions between obesity and infection has been prompted by the influenza H1N1 pandemic, which has shown that obesity affects the disease course and increases the mortality rate in this condition. ${ }^{24-32}$ Half of Californians $\geqslant 20$ years of age hospitalized with the $2009 \mathrm{H} 1 \mathrm{~N} 1$ infection were obese. ${ }^{24}$ One prospective, observational and multicenter study undertaken in 144 ICUs in Spain indicated that obesity was associated with higher ICU resource consumption and longer ICU length of stay in H1N1 influenza. ${ }^{33}$ One review of studies originating from the Southern hemisphere indicated that obesity and morbid obesity were more commonly reported as the level of health care increased in patients with $\mathrm{H} 1 \mathrm{~N} 1$ infection. ${ }^{29}$ Interestingly, obesity has been shown to be a particularly significant risk factor among patients $<60$ years of age. ${ }^{25}$ Obesity has also been shown to be a risk factor for mortality in patients with H1N1 infection-related community-acquired bacterial pneumonia. ${ }^{34} \mathrm{~A}$ recent systematic review and meta-analysis including a total of 3059 subjects confirmed findings in individual cohort studies indicating that obesity is associated with higher risks of ICU admission or death in patients with influenza $A(\mathrm{H} 1 \mathrm{~N} 1)$ infection. ${ }^{35}$ One recent global study conducted by World Health Organization included 70000 laboratory confirmed cases with $\mathrm{H} 1 \mathrm{~N} 1$ from nearly 20 countries indicated a clear association between obesity and poor outcome in $\mathrm{H} 1 \mathrm{~N} 1 .^{36}$

Data on the impact of obesity on the outcome of influenza virus infections other than $\mathrm{H} 1 \mathrm{~N} 1$ are scant. A recent cohort study by Kwong et al. $^{37}$ over 12 influenza seasons aimed to examine the association between obesity and respiratory hospitalizations during seasonal influenza epidemics. They showed that severely obese patients are at increased risk for respiratory hospitalization during influenza seasons. BMI data in this study were based on self-reported height and weight.

The mechanisms underlying these findings have not been fully established. Excessive proinflammatory cytokine release is a key determinant in severe $\mathrm{H} 1 \mathrm{~N} 1$ infection, ${ }^{38}$ and the pathogenesis of severe influenza infection shares properties similar to those in sepsis syndrome. One recent study has shown that the obese evince more intense interleukin- 8 release in $\mathrm{H} 1 \mathrm{~N} 1$ infection as compared with normal-weight individuals. ${ }^{38}$ Sheridan et al. ${ }^{39}$ have shown that obesity is associated with impaired immune response to influenza vaccination in humans. In animal studies diet induced obese mice have been shown to be more susceptible to morbidity and mortality during influenza infection than lean mice due to altered innate immune responses characterized by minimal induction of interferon-alpha/beta, delayed expression of proinflammatory cytokines and chemokines, impaired natural killer cytotoxicity and impaired dendritic cell presentation. Thus, obesity interferes with cellular responses during influenza infection, leading to alterations in the T-cell population that ultimately may be detrimental to the host. ${ }^{40}$

The impact of obesity on infection susceptibility in $\mathrm{H} 1 \mathrm{~N} 1$ infection has not been established. As most patients with 


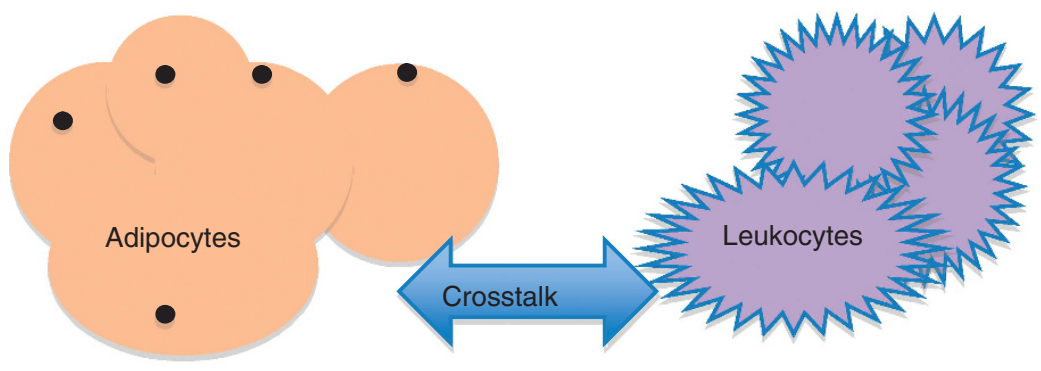

\begin{tabular}{|ll|}
\hline a & \\
Altered secretion of \\
Leptin $\quad$ TNF-alpha & MCP-1 \\
Adiponectin & IL-6 \\
Resistin & Visfatin \\
Omentin & IFN-alpha/beta \\
\end{tabular}

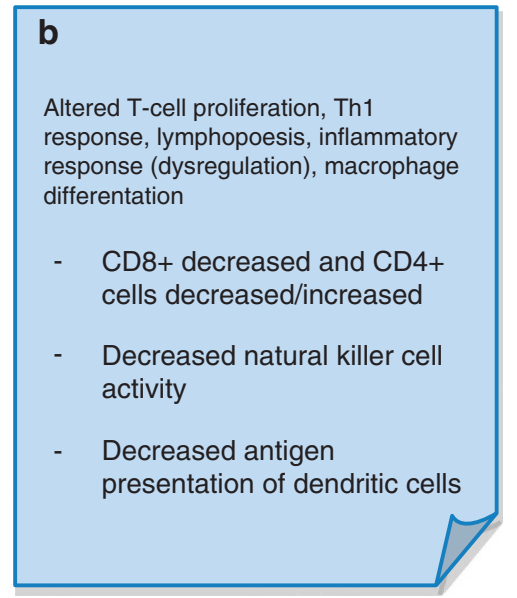

Figure 1. Interactions between adipocytes and leukocytes are complex. Obesity affects cross-talk between these cells resulting in dysregulation of immune system. Central adipokines and cytokines involved are given in box a and central leukocyte functions associated with this cross-talk in box b. IL, interleukin; MCP-1, monocyte chemoattractant protein-1; Th, T-helper, TNF, tumor necrosis factor.

influenza have mild-to-moderate disease with no need for hospitalization or contact with health care, the effect of obesity on the susceptibility to influenza has been difficult to assess. Influenza pandemic has shown that BMI is not a measure routinely recorded on patients admitted to hospital or health care institutions.

In conclusion, obesity has been shown to be associated with adverse outcome in pandemic H1N1 infection. There are no data on the association between obesity and the risk of influenza virus infection.

\section{URINARY TRACT INFECTIONS}

Several studies have studied the risk of urinary tract infection (UTI) in obese. The earliest study in this field did not indicate an association between obesity and increased risk of UTI; a large epidemiological study conducted in the 1980s of 17032 women taking part in the Oxford Family Planning Association contraceptive study indicated that obesity was associated with a decreased risk of UTI. ${ }^{13}$ Vessey et al. ${ }^{13}$ used BMI $\geqslant 24$ as an obesity definition, which differs from the current obesity definition. Recent studies have consistently shown that obesity increases the risk of UTI. A recent cohort study by Semins et al. ${ }^{41}$ with a total of 95598 subjects indicated that obesity is a risk factor for UTI. As regards pyelonephritis, the obese were nearly five times more likely to be diagnosed than were the nonobese; females were at particularly higher risk. ${ }^{41}$ Obesity proved to be a risk factor for UTI in a cohort study of male patients with diabetes mellitus ${ }^{42}$ has been shown to predispose to UTI after traumatic injury $^{43}$ and ICU-acquired UTIs. ${ }^{44}$ Obesity has been shown to be a risk factor for UTI in pregnant woman ${ }^{45}$ and during the postpartum period. ${ }^{46} \mathrm{~A}$ retrospective review and analysis of adult postoperative complications after noncardiac moderate or major surgery indicated that obesity confers a risk factor for UTI in these patients. ${ }^{47}$ In conclusion, several recent studies have shown an association between obesity and an increased risk of UTI. One large epidemiological study conducted in the 1980s showed opposing results, which may originate from methodological differences. There are no data on the effect of obesity on the outcome of UTI.

\section{PERIODONTITIS}

Obesity has been shown to be associated with an increased risk of periodontitis, ${ }^{48}$ having been shown to predict it independently of smoking. ${ }^{48} \mathrm{~A}$ recent meta-analysis has likewise indicated a statistically significant positive association between overweight and obesity and the risk of periodontitis. ${ }^{49}$ One other recent metaanalysis also indicated a consistently positive association with obesity in the development of periodontal disease. The authors concede that with few high-quality longitudinal studies it is not possible to distinguish the temporal order of events, this limiting the evidence that obesity is a risk factor for periodontal disease or in conversely, that periodontitis might increase the risk of weight gain. $^{50}$

Interestingly, in animal models (for example, rats) chronic administration of lipopolysaccharide and proteases induces periodontal inflammation and hepatic steatosis, ${ }^{51}$ and one cohort study has indicated that the severity of periodontal disease is associated with the development of glucose intolerance in non-diabetics. ${ }^{52}$

\section{NOSOCOMIAL INFECTIONS AND SURGICAL INFECTIONS}

Nosocomial infections incur substantial clinical and economic costs. ${ }^{53}$ Cohort studies indicate an association between obesity and the risk of nosocomial infections. ${ }^{12,54} \mathrm{~A}$ recent retrospective case-control study has shown obesity to be an independent predictor of nosocomial bloodstream infection in older adults. ${ }^{54}$ 


\section{ICU AND TRAUMA PATIENTS}

In retrospective and prospective studies, obesity has been shown to be an independent risk factor for infection after trauma. ${ }^{43,55,56}$ Obese patients had a more than twofold increase in the risk of acquiring a bloodstream, urinary tract or respiratory infection in a prospective cohort study of critically ill trauma patients. ${ }^{43}$

Obesity has been shown in several cohort studies to have an impact on the infection risk in critically ill ICU patients. ${ }^{43,57-59}$ Obesity has been shown to be an independent risk factor for ICUacquired catheter and blood stream infections in one prospective observational study. ${ }^{57}$ The authors concluded that one reason for this observation may be explained by the relative difficulty in obtaining venous access in these patients. ${ }^{57}$ A large multicenter prospective study of nearly 200 ICUs in 24 European countries showed that obese and very obese patients more frequently developed ICU-acquired infections than patients in lower BMI categories. $^{58}$ In this study by Sakr et al. ${ }^{58} \mathrm{BMI}$ was prospectively measured at admission to the study ICU. One risk-adjusted matched cohort study indicated that obesity was associated with an increased risk of ICU-associated infections such as septic shock and ventilator-associated pneumonia. ${ }^{59}$ However, obesity was not associated with any increased risk of infection-related case fatality in these patients. ${ }^{59}$ One prospective multicenter matched epidemiologic study, again, indicated no association between obesity and the risk of catheter-related infection or ventilator associated pneumonia. ${ }^{60}$ However, the study in question compared severely obese $(\mathrm{BMI} \geqslant 35)$ with nonobese $(\mathrm{BMI}<30)$ leaving the group of those with $\mathrm{BMI} \geqslant 30$ to $<35$ out of the study. In this study, patients were weighed at ICU admission (lift bed scale).

In conclusion, several studies indicate an association between obesity and the risk of ICU-related or posttraumatic infections, but not all have confirmed this. One potential bias in studies of this field is the challenges in obtaining BMI data in critically ill patients, and weight measured at admission may not reflect patients' real weight because of vascular fluid volume depletion.

\section{SURGICAL INFECTIONS}

Prospective and retrospective cohort studies have indicated that obesity is associated with a significantly increased risk of skin and soft-tissue infection (SSI) after surgery. ${ }^{61-64}$

\section{INFECTIONS FOLLOWING GASTROSURGERY}

Overweight and obesity have been shown to be a risk factor for infection after pancreatoduodenectomy in cohort studies. ${ }^{65,66}$ Obesity has been shown to be associated with a higher risk of post-operative pelvic abscesses after cancer surgery ${ }^{67}$ and a predictor for surgical-site infection after hepatic resection. ${ }^{68}$ In laparoscopic bariatric procedures, the super obese group proved to have a significantly greater incidence of postoperative complications, including superficial and deep wound infections, sepsis, septic shock and 30-day mortality. ${ }^{69}$ One study of patients undergoing colectomy has shown that morbidly obese patients had a higher risk of surgical-site infection as compared with normal-weight subjects, whereas the occurrence of pneumonia UTI or 30-day mortality did not differ significantly by BMI. ${ }^{70}$ Gervaz et $a l^{71}$ have shown that obesity was strongly associated with postoperative SSI after colon or rectum surgery and a simple clinical score based on four preoperative variables including obesity data was clinically useful in predicting the risk of SSI in these patients. $^{71}$

\section{INFECTIONS FOLLOWING VASCULAR AND CARDIAC SURGERY}

Obesity has been in one large cohort study shown to almost double the risk of postoperative SSI after lower extremity bypass. ${ }^{72}$
However, the risk of sepsis or septic shock was not affected by obesity. ${ }^{72}$ Several cohort studies indicate an association between obesity and the risk of sternal wound infection, mediastinitis and bacteremia after cardiac surgery. ${ }^{73-77}$ In one retrospective cohort study, obese diabetic patients had a 7.7-fold increased risk of deep chest infections after controlling for confounders and an independent risk factor for superficial surgical-site infections. $^{78} \mathrm{~A}$ recent nested case-control study indicated that obesity is a risk factor for SSI after central venous catheterrelated infection in cardiac surgery. ${ }^{79}$ Several cohort studies have identified as an independent risk factor for leg-harvest-site infection. $^{80,81}$

\section{INFECTIONS FOLLOWING ORTHOPEDIC SURGERY}

Morbid obesity and obesity combined with diabetes are risk factors for periprosthetic infection after total knee arthroplasty. ${ }^{82}$ Cohort and case-control studies indicate that obesity increases the risk of prosthetic hip infection. ${ }^{83,84}$ In a case-control study of pediatric patients undergoing spinal surgery, obesity was a risk factor for $\mathrm{SSI}^{85}$

In conclusion, several studies indicate that obesity increases the risk of surgical infections. The association seems to be most evident in vascular, cardiac and orthopedic surgery.

\section{OBESITY AND THE OUTCOME OF NOSOCOMIAL AND SURGICAL INFECTIONS}

The impact of obesity on the outcome of various surgical or nosocomial infections remains obscure. One retrospective cohort study in appendicitis patients indicated that the outcome of appendicitis pre- or postoperatively did not differ between obese and non-obese subjects. Only the length of stay in hospital in those with perforation was adversely affected by obesity. ${ }^{86}$

One recent study on patients with durable mechanical support at a single institution from January 2000 to December 2008 showed that obese patients, as compared with the non-obese, had higher incidence rates of sepsis $(64.5 \%$ vs $34.7 \%$, respectively, $P=0.006)$ and reoperation for infectious complications $(34.2 \%$ vs $13.3 \%$, respectively, $P=0.014){ }^{87}$

\section{PANCREATITIS}

Data on the potential effect of obesity on the risk of acute pancreatitis are scant. One large epidemiological study has indicated that obesity is a risk factor for gallstones, gallbladder disease and pancreatitis. ${ }^{88}$

Several studies indicate an association between obesity and severe pancreatitis. Obesity has been shown to predispose to local complications of pancreatitis such as pancreatic pseudocysts, abscess and necrosis. ${ }^{89,90}$ Visceral obesity and adipose tissue have proved particularly important as underlying factors in the pathophysiology of severe diseases. It has been shown that adipokines secreted from adipose tissues enhance and maintain systemic inflammation in acute pancreatitis. ${ }^{91,92}$ The severity of acute pancreatitis in obese patients and in patients with central fat distribution seems to be related to the amplification of systemic inflammatory reaction. ${ }^{91}$ A meta-analysis published in 2004 indicated that severe acute pancreatitis is significantly more common in the obese, and that obesity is associated with systemic and local complications. ${ }^{89}$ However, mortality was not significantly higher in obese than in non-obese subjects. ${ }^{89}$ On the other hand, an updated meta-analysis of the same group in 2006 indicated that obesity was significantly associated with increased mortality in acute pancreatitis. ${ }^{90}$ In conclusion, obesity is a risk factor for severe pancreatitis but data on the potential effect of obesity on the risk of acute pancreatitis are limited. 


\section{SKIN INFECTIONS AND CELLULITIS}

Obesity causes changes in skin barrier function, the lymph system, collagen structure and function, and wound healing. Evidence suggests that the vascular supply is impaired in obese persons and obesity affects both macro- and microcirculation. Obesity is associated with a wide range of skin diseases. ${ }^{23}$

Case-control studies indicate an increased risk of cellulitis and skin infections in the overweight ${ }^{93}$ and obese. ${ }^{94,95}$ Björnsdottir et $a .^{96}$ in a prospective case-control study showed obesity to constitute a risk factor for cellulitis in a univariate model, but in a multivariate model the finding no longer persisted after controlling for other factors. However, several studies have indicated that obesity predisposes to erysipelas independently of potential confounders. ${ }^{93,94}$ One prospective cross-sectional study has indicated that obesity is a frequent disease in patients with erysipelas. ${ }^{97}$ Data indicate that obesity predisposes to a significantly increased risk of recurrent soft-tissue infections. ${ }^{94,98}$

Data on the association between obesity and the outcome of skin infections are limited. A prospective cohort study has indicated the outcome of cellulitis to be worse in the morbidly obese as compared with non-obese subjects. ${ }^{99}$

To summarize, several well-conducted case-control studies indicate an association between obesity and the risk of cellulitis, but the data on the association between obesity and the outcome of skin infections are limited.

\section{VIRAL HEPATITIS}

Cohort studies have shown obesity to be related to an increased risk of hepatic steatosis and fibrosis in non-diabetic patients with chronic hepatitis C infection. ${ }^{100,101}$ Overweight has been observed to have an adverse effect on the progression of chronic HCV liver disease, with diminished response to antiviral therapy. ${ }^{100,101}$ Interestingly, significant changes in insulin resistance and adipocytokines have been noted to occur under viral treatment, irrespective of virological outcome. ${ }^{100}$ Experimental and clinical evidence has proved the contribution of HCV in the development of insulin resistance and diabetes in human HCV infection. ${ }^{102,103}$ A recent cohort study has indicated that compared with subjects with seroprotective titers from hepatitis $B$ vaccination, those without protective titers of anti-HBs after vaccination or those with natural infection with hepatitis B have a higher risk of metabolic syndrome. ${ }^{104}$ The study in question was limited by the cross-sectional design and did not answer the causal relationship between the status of hepatitis B immunity and metabolic syndrome. ${ }^{104}$ In conclusion, obesity is associated with an increased risk of hepatic steatosis in patients with chronic hepatitis $C$ infection.

\section{ANTIMICROBIAL DOSING IN OBESITY}

The data on right dosing of antimicrobials in obesity are limited. Whereas there are clear recommendations for antimicrobial dosing in children, no such data are available for obese patients. ${ }^{7}$ A correct understanding of the influence of obesity on antimicrobial drug dosing is crucial to achieve maximum safety and effectiveness in therapy. Changes in the pharmacodynamics of drugs in obese are highly variable and depend on multiple factors, including degree of obesity, organ function and on drug characteristics. ${ }^{105}$ Obesity affects volume of distribution $\left(V_{\mathrm{d}}\right)$ of drugs and thus increases the $V_{d}$ of lipophilic drugs (for example, fluoroquinolones) and decreases the $V_{d}$ of hydrophilic drugs (for example, amikacin and tobramycin). ${ }^{105}$ Several studies indicate that physicians frequently underdose antimicrobials in obese patients. $^{106,107}$

Choosing appropriate antibiotic dosages is extremely challenging when treating obese patients with severe, deep-seated infections and multiple organ failure. ${ }^{108}$ Previous data indicate that the penetration process of antimicrobials into the interstitial space fluid is impaired in obese subjects. ${ }^{109}$ There are some data on the appropriate dosing of antimicrobials, which require drug concentration monitoring such as vancomycin and aminoglycosides, but the right dosing of most antimicrobials is unclear. ' Data indicate inadequate plasma concentrations for obese patients, when standard treatment doses of vancomycin are used. ${ }^{107} \mathrm{~A}$ recent multicenter study indicated that vancomycin concentration in obese subjects was $<30 \%$ of optimal therapeutic concentrations when a standard dosing ( $2 \mathrm{~g}$ per day) was used. ${ }^{107}$ One recent report by Pea et al. ${ }^{108}$ introduced the use of real-time therapeutic drug monitoring by high-performance liquid chromatography system and showed that this approach would be invaluable in ensuring rapid clinical response and preventing drug-related toxicity in a morbidly obese patient with livethreatening cellulitis and organ failure treated with high-dose daptomycin plus continuous infusion meropenem. The authors stressed the point that in considering dosing strategies for hydrophilic antimicrobials in obese patients, clinicians should bear in mind that standard methods of estimating renal function are inaccurate. ${ }^{108}$ Rapid and easy methods for bedside monitoring of drug concentrations and toxicity in the case of obese patients are eagerly awaited. Some data indicate that plasma drug concentrations may not predict tissue concentrations and that therefore dosing on the basis of weight-correction factors may potentially result in subtherapeutic concentrations of the drug in tissues. ${ }^{109}$ Morbid obesity has been shown to affect the blood and tissue levels of prophylactic antimicrobials. ${ }^{110}$

After the association between obesity and poor outcome in H1N1 infection became evident, one study has investigated the appropriate dosing of oseltamivir in obesity. The OPTIMO trial was a single-center, non-randomized, open-label pharmacokinetic study of single-dose and steady-state oral oseltamivir phosphate and its carboxylate metabolite in healthy, morbidly obese and healthy, non-obese subjects. With single and multiple dosing, the systemic exposure to oseltamivir was decreased but that of oseltamivir carboxylate was largely unchanged. The authors concluded that an oseltamivir dose adjustment for body weight would not be needed in morbidly obese individuals. ${ }^{111}$ Studies that correlate clinical outcomes with plasma concentrations of oseltamivir and viral susceptibility are needed in the future.

One recent study investigated the pharmacokinetics of intravenous levofloxacin administered at $750 \mathrm{mg}$ in obese adults. The peak concentrations of levofloxacin were comparable to those seen with normal-weight individuals. However, the area under the concentration-time curve and clearance were quite variable. ${ }^{112}$ Another recent study showed that obese patients with severe infections caused by high-minimal inhibitory concentration may require greater ciprofloxacin dosages. ${ }^{13}$

Many Gram-negative bacteria, such as Pseudomonas aeruginosa and Stenotrophomonas maltophila survive with inadequate blood antimicrobial drug concentrations and may develop antimicrobial resistance. Thus, some authors recommend using more frequent dosing intervals in obese patients in the treatment of organisms with high minimal inhibitory concentration. ${ }^{7,114}$ However, these recommendations are based on single patient cases and no randomized studies have been conducted to make firm conclusions on this topic.

In conclusion, obesity has been shown to alter the pharmacokinetics and pharmacodynamics of antimicrobials, and several studies indicate that underdosing antimicrobials is common in the treatment of obese patients with infection. However, there are no guidelines or randomized studies on this topic. Further studies should focus on the use of antimicrobials in obesity.

\section{CONCLUSIONS}

The recent pandemic influenza epidemic and studies on several other infectious diseases have drawn our attention to the 
association between the obesity epidemic and infectious diseases. However, the associations have not been assessed in a wide range of infectious conditions. The exact mechanisms underlying obesity-related changes in the course of infectious diseases are not established. Multiple factors may be involved, for example, obesity-related comorbidities, immunological effects and pharmacological issues. As the cause-effect relationship between obesity and infection remains obscure in many infectious diseases, further studies are warranted. Current data indicate that obesity has adverse effects on the disease course of pancreatitis and H1N1 infection, and increases the risk of postsurgical and nosocomial infections. With increasing rates of obesity, we may expect the mortality and morbidity in infectious diseases to increase. Routine measurement of BMI in patients visiting outpatient clinics and in hospitalized patients would potentially increase research possibilities in this area. As the systematic evaluation of drug pharmacokinetics and pharmacodynamics in obese patients are limited, this should be incorporated into the drug development process.

\section{CONFLICT OF INTEREST}

The authors declare no conflict of interest.

\section{ACKNOWLEDGEMENTS}

This work was supported by a grant from the Medical Research Fund of Tampere University Hospital. The author's work was independent of the funder (the funding source had no involvement). This work was carried out in the Tampere University Hospital and in the University of Tampere Medical School, Tampere, Finland.

\section{REFERENCES}

1 Berghofer A, Pischon T, Reinhold T, Apovian CM, Sharma AM, Willich SN. Obesity prevalence from a European perspective: a systematic review. BMC Public Health 2008; 8: 200.

2 WHO. WHO obesity: preventing and managing the global epidemic. Report of the WHO consultation. World Health Organ Tech Rep Ser 2000; 894: 1-253.

3 Abdullah A, Wolfe R, Stoelwinder JU, de Courten M, Stevenson C, Walls HL et al. The number of years lived with obesity and the risk of all-cause and causespecific mortality. Int J Epidemiol 2011; 40: 985-996.

4 Huttunen R, Syrjänen J. Obesity and the outcome of infection. Lancet Infect Dis 2010; 10: 442-443.

5 Falagas ME, Kompoti M. Obesity and infection. Lancet Infect Dis 2006; 6 : 438-446.

6 Falagas ME, Athanasoulia AP, Peppas G, Karageorgopoulos DE. Effect of body mass index on the outcome of infections: a systematic review. Obes Rev 2009; 10: 280-289.

7 Falagas ME, Karageorgopoulos DE. Adjustment of dosing of antimicrobial agents for bodyweight in adults. Lancet 2010; 375: 248-251.

8 Kornum JB, Norgaard M, Dethlefsen C, Due KM, Thomsen RW, Tjonneland A et al. Obesity and risk of subsequent hospitalisation with pneumonia. Eur Respir $J$ 2010; 36: 1330-1336.

9 Almirall J, Bolibar I, Serra-Prat M, Roig J, Hospital I, Carandell E et al. New evidence of risk factors for community-acquired pneumonia: a population-based study. Eur Respir J 2008; 31: 1274-1284.

10 Baik I, Curhan GC, Rimm EB, Bendich A, Willett WC, Fawzi WW. A prospective study of age and lifestyle factors in relation to community-acquired pneumonia in US men and women. Arch Intern Med 2000; 160: 3082-3088.

11 Schnoor M, Klante T, Beckmann M, Robra BP, Welte T, Raspe $\mathrm{H}$ et al. Risk factors for community-acquired pneumonia in German adults: the impact of children in the household. Epidemiol Infect 2007; 135: 1389-1397.

12 Choban PS, Heckler R, Burge JC. Flancbaum L Increased incidence of nosocomial infections in obese surgical patients. Am Surg 1995; 61: 1001-1005.

13 Vessey MP, Metcalfe MA, McPherson K, Yeates D. Urinary tract infection in relation to diaphragm use and obesity. Int J Epidemiol 1987; 16: 441-444.

14 Marti A, Marcos A, Martinez JA. Obesity and immune function relationships. Obes Rev 2001; 2: 131-140.

15 Nave H, Beutel G, Kielstein JT. Obesity-related immunodeficiency in patients with pandemic influenza H1N1. Lancet Infect Dis 2011; 11: 14-15.

16 Havel PJ, Kasim-Karakas S, Mueller W, Johnson PR, Gingerich RL, Stern JS. Relationship of plasma leptin to plasma insulin and adiposity in normal weight and overweight women: effects of dietary fat content and sustained weight loss. J Clin Endocrinol Metab 1996; 81: 4406-4413.

17 Koch A, Sanson E, Voigt S, Helm A, Trautwein C, Tacke F. Serum adiponectin upon admission to the intensive care unit may predict mortality in critically ill patients. J Crit Care 2011; 26: 166-174.

18 Festa A, D'Agostino Jr R, Williams K, Karter AJ, Mayer-Davis EJ, Tracy RP et al. The relation of body fat mass and distribution to markers of chronic inflammation. Int J Obes Relat Metab Disord 2001; 25: 1407-1415.

19 Brown CV, Neville AL, Rhee P, Salim A, Velmahos GC, Demetriades D. The impact of obesity on the outcomes of 1,153 critically injured blunt trauma patients. J Trauma 2005; 59: 1048-1051discussion 1051.

20 Anzueto A, Frutos-Vivar F, Esteban A, Bensalami N, Marks D, Raymondos K et al. Influence of body mass index on outcome of the mechanically ventilated patients. Thorax 2011; 66: 66-73.

21 Hogue Jr. CW, Stearns JD, Colantuoni E, Robinson KA, Stierer T, Mitter N et al. The impact of obesity on outcomes after critical illness: a meta-analysis. Intensive Care Med 2009; 35: 1152-1170.

22 Ashburn DD, DeAntonio A, Reed MJ. Pulmonary system and obesity. Crit Care Clin 2010; 26: 597-602.

23 Yosipovitch G, DeVore A, Dawn A. Obesity and the skin: skin physiology and skin manifestations of obesity. J Am Acad Dermatol 2007; 56: 901-916quiz 917-20.

24 Louie JK, Acosta M, Samuel MC, Schechter R, Vugia DJ, Harriman K et al. A novel risk factor for a novel virus: obesity and 2009 pandemic influenza A (H1N1). Clin Infect Dis 2011; 52: 301-312.

25 Yu H, Feng Z, Uyeki TM, Liao Q, Zhou L, Feng L et al. Risk factors for severe illness with 2009 pandemic influenza A (H1N1) virus infection in China. Clin Infect Dis 2011; 52: 457-465.

26 Lucas S. Predictive clinicopathological features derived from systematic autopsy examination of patients who died with $\mathrm{A} / \mathrm{H} 1 \mathrm{~N} 1$ influenza infection in the UK 2009-10 pandemic. Health Technol Assess 2010; 14: 83-114.

27 Fuhrman C, Bonmarin I, Bitar D, Cardoso T, Duport N, Herida M et al. Adult intensive-care patients with 2009 pandemic influenza $A(\mathrm{H} 1 \mathrm{~N} 1)$ infection. Epidemiol Infect 2011; 139: 1202-1209.

28 Santa-Olalla Peralta P, Cortes-Garcia M, Vicente-Herrero M, Castrillo-Villamandos C, Arias-Bohigas P, Pachon-del Amo I et al. Risk factors for disease severity among hospitalised patients with 2009 pandemic influenza A (H1N1) in Spain April - December 2009. Euro Surveill 2010; 15: pii: 19667.

29 Falagas ME, Koletsi PK, Baskouta E, Rafailidis PI, Dimopoulos G, Karageorgopoulos DE. Pandemic A(H1N1) 2009 influenza: review of the Southern Hemisphere experience. Epidemiol Infect 2011; 139: 27-40.

30 Viasus D, Pano-Pardo JR, Pachon J, Campins A, Lopez-Medrano F, Villoslada A et al. Factors associated with severe disease in hospitalized adults with pandemic (H1N1) 2009 in Spain. Clin Microbiol Infect 2011; 17: 738-746.

31 Nguyen-Van-Tam JS, Openshaw PJ, Hashim A, Gadd EM, Lim WS, Semple MG et al. Risk factors for hospitalisation and poor outcome with pandemic $\mathrm{A} / \mathrm{H} 1 \mathrm{~N} 1$ influenza: United Kingdom first wave (May-September 2009). Thorax 2010 65: 645-651.

32 Satterwhite L, Mehta A, Martin GS. Novel findings from the second wave of adult pH1N1 in the United States. Crit Care Med 2010; 38: 2059-2061.

33 Diaz E, Rodriguez A, Martin-Loeches I, Lorente L, del Mar Martin M, Pozo JC et al. Impact of obesity in patients infected with 2009 influenza A(H1N1). Chest 2010; 139: $382-386$.

34 Riquelme R, Jimenez P, Videla AJ, Lopez H, Chalmers J, Singanayagam A et al. Predicting mortality in hospitalized patients with $2009 \mathrm{H} 1 \mathrm{~N} 1$ influenza pneumonia. Int J Tuberc Lung Dis 2011; 15: 542-566.

35 Fezeu L, Julia C, Henegar A, Bitu J, Hu FB, Grobbee DE et al. Obesity is associated with higher risk of intensive care unit admission and death in influenza A (H1N1) patients: a systematic review and meta-analysis. Obes Rev 2011; 12: 653-659.

36 Van Kerkhove MD, Vandemaele KA, Shinde V, Jaramillo-Gutierrez G, Koukounari A, Donnelly CA et al. Risk factors for severe outcomes following 2009 influenza A (H1N1) infection: a global pooled analysis. PLoS Med 2011; 8: e1001053.

37 Kwong JC, Campitelli MA. Rosella LC Obesity and respiratory hospitalizations during influenza seasons in Ontario, Canada: a cohort study. Clin Infect Dis 2011 53: 413-421.

38 Hagau N, Slavcovici A, Gonganau DN, Oltean S, Dirzu DS, Brezoszki ES et al. Clinical aspects and cytokine response in severe H1N1 influenza A virus infection. Crit Care 2010; 14: R203.

39 Sheridan PA, Paich HA, Handy J, Karlsson EA, Hudgens MG, Sammon AB et al. Obesity is associated with impaired immune response to influenza vaccination in humans. Int J Obes (Lond) 2011; e-pub ahead of print 25 October 2011; doi:10.1038/ijo.2011.208.

40 Smith AG, Sheridan PA, Tseng RJ, Sheridan JF, Beck MA. Selective impairment in dendritic cell function and altered antigen-specific CD8 + T-cell responses in 
diet-induced obese mice infected with influenza virus. Immunology 2009; 126: 268-279.

41 Semins MJ, Shore AD, Makary MA, Weiner J, Matlaga BR. The impact of obesity on urinary tract infection risk. Urology 2012; 79: 266-269.

42 Ribera MC, Pascual R, Orozco D, Perez Barba C, Pedrera V, Gil V. Incidence and risk factors associated with urinary tract infection in diabetic patients with and without asymptomatic bacteriuria. Eur J Clin Microbiol Infect Dis 2006; 25: 389-393.

43 Bochicchio GV, Joshi M, Bochicchio K, Nehman S, Tracy JK, Scalea TM. Impact of obesity in the critically ill trauma patient: a prospective study. J Am Coll Surg 2006; 203: 533-538.

44 Wurzinger B, Dunser MW, Wohlmuth $\mathrm{C}$, Deutinger MC, Ulmer $\mathrm{H}$, Torgersen $\mathrm{C}$ et al. The association between body-mass index and patient outcome in septic shock: a retrospective cohort study. Wien Klin Wochenschr 2010; 122: 31-36.

45 Basu JK, Jeketera CM, Basu D. Obesity and its outcomes among pregnant South African women. Int J Gynaecol Obstet 2010; 110: 101-104.

46 Usha Kiran TS, Hemmadi S, Bethel J, Evans J. Outcome of pregnancy in a woman with an increased body mass index. Bjog 2005; 112: 768-772.

47 Bamgbade OA, Rutter TW, Nafiu OO, Dorje P. Postoperative complications in obese and nonobese patients. World J Surg 2007; 31: 556-560; discussion 561.

48 Saito T, Shimazaki Y, Sakamoto M. Obesity and periodontitis. N Engl J Med 1998; 339: 482-483.

49 Suvan J, D'Aiuto F, Moles DR, Petrie A, Donos N. Association between overweight/obesity and periodontitis in adults. A systematic review. Obes Rev 2011; 12: e381-e404.

50 Chaffee BW, Weston SJ. Association between chronic periodontal disease and obesity: a systematic review and meta-analysis. J Periodontol 2010; 81: 1708-1724.

51 Tomofuji T, Ekuni D, Yamanaka R, Kusano H, Azuma T, Sanbe T et al. Chronic administration of lipopolysaccharide and proteases induces periodontal inflammation and hepatic steatosis in rats. J Periodontol 2007; 78: 1999-2006.

52 Saito $T$, Shimazaki $Y$, Kiyohara $Y$, Kato I, Kubo M, lida $M$ et al. The severity of periodontal disease is associated with the development of glucose intolerance in non-diabetics: the Hisayama study. J Dent Res 2004; 83: 485-490.

53 Eber MR, Laxminarayan R, Perencevich EN, Malani A. Clinical and economic outcomes attributable to health care-associated sepsis and pneumonia. Arch Intern Med 2010; 170: 347-353.

54 Kaye KS, Marchaim D, Chen TY, Chopra T, Anderson DJ, Choi Y et al. Predictors of nosocomial bloodstream infections in older adults. J Am Geriatr Soc 2011; 59: 622-627.

55 Edmonds RD, Cuschieri J, Minei JP, Rosengart MR, Maier RV, Harbrecht BG et al. Body adipose content is independently associated with a higher risk of organ failure and nosocomial infection in the nonobese patient postinjury. $J$ Trauma 2011; 70: 292-298.

56 Serrano PE, Khuder SA, Fath JJ. Obesity as a risk factor for nosocomial infections in trauma patients. J Am Coll Surg 2010; 211: 61-67.

57 Dossett LA, Dageforde LA, Swenson BR, Metzger R, Bonatti H, Sawyer RG et al. Obesity and site-specific nosocomial infection risk in the intensive care unit. Surg Infect (Larchmt) 2009; 10: 137-142.

58 Sakr Y, Madl C, Filipescu D, Moreno R, Groeneveld J, Artigas A et al. Obesity is associated with increased morbidity but not mortality in critically ill patients. Intensive Care Med 2008; 34: 1999-2009.

59 Bercault N, Boulain T, Kuteifan K, Wolf M, Runge I, Fleury JC. Obesity-related excess mortality rate in an adult intensive care unit: a risk-adjusted matched cohort study. Crit Care Med 2004; 32: 998-1003.

60 Frat JP, Gissot V, Ragot S, Desachy A, Runge I, Lebert C et al. Impact of obesity in mechanically ventilated patients: a prospective study. Intensive Care Med 2008; 34: 1991-1998.

61 Olsen MA, Higham-Kessler J, Yokoe DS, Butler AM, J Vostok, KB Stevenson et al. Developing a risk stratification model for surgical site infection after abdominal hysterectomy. Infect Control Hosp Epidemiol 2009; 30: 1077-1083.

62 Waisbren E, Rosen H, Bader AM, Lipsitz SR, Rogers Jr. SO, Eriksson E. Percent body fat and prediction of surgical site infection. J Am Coll Surg 2010; 210: 381-389.

63 Di Leo A, Piffer S, Ricci F, Manzi A, Poggi E, Porretto V et al. Surgical site infections in an Italian surgical ward: a prospective study. Surg Infect (Larchmt) 2009; 10: 533-538.

64 Beldi G, Bisch-Knaden S, Banz V, Muhlemann K, Candinas D. Impact of intraoperative behavior on surgical site infections. Am J Surg 2009; 198: 157-162.

65 Su Z, Koga R, Saiura A, Natori T, Yamaguchi T, Yamamoto J. Factors influencing infectious complications after pancreatoduodenectomy. J Hepatobiliary Pancreat Sci 2010; 17: 174-179.

66 Greenblatt DY, Kelly KJ, Rajamanickam V, Wan Y, Hanson T, Rettammel R et al. Preoperative factors predict perioperative morbidity and mortality after pancreaticoduodenectomy. Ann Surg Oncol 2011; 18: 2126-2135.
67 Healy LA, Ryan AM, Sutton E, Younger K, Mehigan B, Stephens R et al. Impact of obesity on surgical and oncological outcomes in the management of colorectal cancer. Int J Colorectal Dis 2010; 25: 1293-1299.

68 Okabayashi T, Nishimori I, Yamashita K, Sugimoto T, Yatabe T, Maeda H et al. Risk factors and predictors for surgical site infection after hepatic resection. $J$ Hosp Infect 2009; 73: 47-53.

69 Kakarla VR, Nandipati K, Lalla M, Castro A, Merola S. Are laparoscopic bariatric procedures safe in superobese (BMI $>/=50 \mathrm{~kg} / \mathrm{m}(2))$ patients? An NSQIP data analysis. Surg Obes Relat Dis 2011; 7: 452-458.

70 Merkow RP, Bilimoria KY, McCarter MD, Bentrem DJ. Effect of body mass index on short-term outcomes after colectomy for cancer. J Am Coll Surg 2009; 208: 53-61.

71 Gervaz P, Bandiera-Clerc C, Buchs NC, Eisenring MC, Troillet N, Perneger T et al. Scoring system to predict the risk of surgical-site infection after colorectal resection. Br J Surg 2012; 99: 589-595

72 Giles KA, Hamdan AD, Pomposelli FB, Wyers MC, Siracuse JJ, Schermerhorn ML. Body mass index: surgical site infections and mortality after lower extremity bypass from the National Surgical Quality Improvement Program 2005-2007. Ann Vasc Surg 2010; 24: 48-56.

73 Dodds Ashley ES, Carroll DN, Engemann JJ, Harris AD, Fowler Jr. VG, Sexton DJ et al. Risk factors for postoperative mediastinitis due to methicillin-resistant Staphylococcus aureus. Clin Infect Dis 2004; 38: 1555-1560.

74 Spelman DW, Russo P, Harrington G, Davis BB, Rabinov M, Smith JA et al. Risk factors for surgical wound infection and bacteraemia following coronary artery bypass surgery. Aust N Z J Surg 2000; 70: 47-51.

75 Göl MK, Karahan M, Ulus AT, Erdil N, Iscan Z, Karabiber N et al. Bloodstream, respiratory, and deep surgical wound infections after open heart surgery. J Card Surg 1998; 13: 252-259.

76 Ahmed D, Cheema FH, Ahmed Yl, Schaefle KJ, Azam SI, Sami SA et al. Incidence and predictors of infection in patients undergoing primary isolated coronary artery bypass grafting: a report from a tertiary care hospital in a developing country. J Cardiovasc Surg (Torino) 2011; 52: 99-104.

77 Al-Zaru IM, Ammouri AA, Al-Hassan MA, Amr AA. Risk factors for deep sternal wound infections after cardiac surgery in Jordan. J Clin Nurs 2010; 19: $1873-1881$.

78 Olsen MA, Lock-Buckley P, Hopkins D, Polish LB, Sundt TM, Fraser VJ. The risk factors for deep and superficial chest surgical-site infections after coronary artery bypass graft surgery are different. J Thorac Cardiovasc Surg 2002; 124: 136-145.

79 Le Guillou V, Tavolacci MP, Baste JM, Hubscher C, Bedoit E, Bessou JP et al. Surgical site infection after central venous catheter-related infection in cardiac surgery. Analysis of a cohort of 7557 patients. J Hosp Infect 2011; 79: 236-241.

80 Sharma M, Fakih MG, Berriel-Cass D, Meisner S, Saravolatz L, Khatib R. Harvest surgical site infection following coronary artery bypass grafting: risk factors, microbiology, and outcomes. Am J Infect Control 2009; 37: 653-657.

81 Olsen MA, Sundt TM, Lawton JS, Damiano Jr. RJ, Hopkins-Broyles D, Lock-Buckley $P$ et al. Risk factors for leg harvest surgical site infections after coronary artery bypass graft surgery. J Thorac Cardiovasc Surg 2003; 126: 992-999.

82 Dowsey MM, Choong PF. Obese diabetic patients are at substantial risk for deep infection after primary TKA. Clin Orthop Relat Res 2009; 467: 1577-1581.

83 Peel TN, Dowsey MM, Daffy JR, Stanley PA, Choong PF, Buising KL. Risk factors for prosthetic hip and knee infections according to arthroplasty site. $J$ Hosp Infect 2011; 79: 129-133.

84 McCalden RW, Charron KD, Macdonald SJ, Bourne RB, Naudie DD. Does morbid obesity affect the outcome of total hip replacement?: an analysis of 3290 THRs. J Bone Joint Surg Br 2011; 93: 321-325.

85 Linam WM, Margolis PA, Staat MA, Britto MT, Hornung R, Cassedy A et al. Risk factors associated with surgical site infection after pediatric posterior spinal fusion procedure. Infect Control Hosp Epidemiol 2009; 30: 109-116.

86 Towfigh S, Chen F, Katkhouda N, Kelso R, Sohn H, Berne TV et al. Obesity should not influence the management of appendicitis. Surg Endosc 2008; 22: 2601-2605.

87 Zahr F, Genovese E, Mathier M, Shullo M, Lockard K, Zomak R et al. Obese patients and mechanical circulatory support: weight loss, adverse events, and outcomes. Ann Thorac Surg 2011; 92: 1420-1426.

88 Torgerson JS, Lindroos AK, Naslund I, Peltonen M. Gallstones, gallbladder disease, and pancreatitis: cross-sectional and 2-year data from the swedish obese subjects (SOS) and SOS reference studies. Am J Gastroenterol 2003; 98: 1032-1041.

89 Martinez J, Sanchez-Paya J, Palazon JM, Suazo-Barahona J, Robles-Diaz G, PerezMateo M. Is obesity a risk factor in acute pancreatitis? A meta-analysis. Pancreatology 2004; 4: 42-48.

90 Martinez J, Johnson CD, Sanchez-Paya J, de Madaria E, Robles-Diaz G, Perez-Mateo M. Obesity is a definitive risk factor of severity and mortality in acute pancreatitis: an updated meta-analysis. Pancreatology 2006; 6: 206-209. 
91 Sempere L, Martinez J, de Madaria E, Lozano B, Sanchez-Paya J, Jover R et al. Obesity and fat distribution imply a greater systemic inflammatory response and a worse prognosis in acute pancreatitis. Pancreatology 2008; 8: 257-264.

92 Evans AC, Papachristou Gl, Whitcomb DC. Obesity and the risk of severe acute pancreatitis. Minerva Gastroenterol Dietol 2010; 56: 169-179.

93 Dupuy A, Benchikhi H, Roujeau JC, Bernard P, Vaillant L, Chosidow O et al. Risk factors for erysipelas of the leg (cellulitis): case-control study. Bmj 1999; 318: 1591-1594.

94 Karppelin M, Siljander T, Vuopio-Varkila J, Kere J, Huhtala H, Vuento R et al. Factors predisposing to acute and recurrent bacterial non-necrotizing cellulitis in hospitalized patients: a prospective case-control study. Clin Microbiol Infect 2010; 16: 729-734.

95 Bartholomeeusen S, Vandenbroucke J, Truyers C, Buntinx F. Epidemiology and comorbidity of erysipelas in primary care. Dermatology 2007; 215: 118-122.

96 Bjornsdottir S, Gottfredsson M, Thorisdottir AS, Gunnarsson GB, Rikardsdottir H, Kristjansson $M$ et al. Risk factors for acute cellulitis of the lower limb: a prospective case-control study. Clin Infect Dis 2005; 41: 1416-1422.

97 Pereira de Godoy JM, Galacini Massari P, Yoshino Rosinha M, Marinelli Brandao R, Foroni Casas AL. Epidemiological data and comorbidities of 428 patients hospitalized with erysipelas. Angiology 2010; 61: 492-494.

98 Sreeramoju P, Porbandarwalla NS, Arango J, Latham K, Dent DL, Stewart RM et al. Recurrent skin and soft tissue infections due to methicillin-resistant Staphylococcus aureus requiring operative debridement. Am J Surg 2011; 201: $216-220$

99 Carratala J, Roson B, Fernandez-Sabe N, Shaw E, del Rio O, Rivera A et al. Factors associated with complications and mortality in adult patients hospitalized for infectious cellulitis. Eur J Clin Microbiol Infect Dis 2003; 22 151-157.

100 Lo lacono O, Venezia G, Petta S, Mineo C, De Lisi S, Di Marco V et al. The impact of insulin resistance, serum adipocytokines and visceral obesity on steatosis and fibrosis in patients with chronic hepatitis C. Aliment Pharmacol Ther 2007; 25: 1181-1191.

101 Delgado-Borrego A, Healey D, Negre B, Christofi M, Sabharwal S, Ludwig DA et al. Influence of body mass index on outcome of pediatric chronic hepatitis $C$ virus infection. J Pediatr Gastroenterol Nutr 2010; 51: 191-197.

102 Tolman KG, Fonseca V, Tan MH, Dalpiaz A. Narrative review: hepatobiliary disease in type 2 diabetes mellitus. Ann Intern Med 2004; 141: 946-956.

103 Shintani Y, Fujie H, Miyoshi H, Tsutsumi T, Tsukamoto K, Kimura S et al. Hepatitis $C$ virus infection and diabetes: direct involvement of the virus in the development of insulin resistance. Gastroenterology 2004; 126: 840-848.

104 Yen SL, Chiu TY, Lin YC, Lee YC, Lee LT, Huang KC. Obesity and hepatitis B infection are associated with increased risk of metabolic syndrome in university freshmen. Int J Obes (Lond) 2008; 32: 474-480.

105 Jain R, Chung SM, Jain L, Khurana M, Lau SW, Lee JE et al. Implications of obesity for drug therapy: limitations and challenges. Clin Pharmacol Ther 2011 90: 77-89.

106 Roe JL, Fuentes JM, Mullins ME. Underdosing of common antibiotics for obese patients in the ED. Am J Emerg Med 2011; e-pub ahead of print 12 December 2011.

107 Hall 2nd RG, Payne KD, Bain AM, Rahman AP, Nguyen ST, Eaton SA et al. Multicenter evaluation of vancomycin dosing: emphasis on obesity. Am J Med 2008; 121: 515-518.

108 Pea F, Cojutti P, Sbrojavacca R, Cadeo B, Cristini F, Bulfoni A et al. TDM-guided therapy with daptomycin and meropenem in a morbidly obese, critically ill patient. Ann Pharmacother 2011; 45: e37.

109 Hollenstein UM, Brunner M, Schmid R, Muller M. Soft tissue concentrations of ciprofloxacin in obese and lean subjects following weight-adjusted dosing Int J Obes Relat Metab Disord 2001; 25: 354-358.

110 Forse RA, Karam B, MacLean LD, Christou NV. Antibiotic prophylaxis for surgery in morbidly obese patients.. Surgery 1989; 106: 750-756; discussion 756-757.

111 Thorne-Humphrey LM, Goralski KB, Slayter KL, Hatchette TF, Johnston BL, McNeil SA. Oseltamivir pharmacokinetics in morbid obesity (OPTIMO trial). J Antimicrob Chemother 2011; 66: 2083-2091.

112 Cook AM, Martin C, Adams VR, Morehead RS. Pharmacokinetics of intravenous levofloxacin administered at 750 milligrams in obese adults. Antimicrob Agents Chemother 2011; 55: 3240-3243.

113 Utrup TR, Mueller EW, Healy DP, Callcut RA, Peterson JD, Hurford WE. High-dose ciprofloxacin for serious gram-negative infection in an obese, critically ill patient receiving continuous venovenous hemodiafiltration. Ann Pharmacother 2010; 44: 1660-1664.

114 Newman D, Scheetz MH, Adeyemi OA, Montevecchi M, Nicolau DP, Noskin GA et al. Serum piperacillin/tazobactam pharmacokinetics in a morbidly obese individual. Ann Pharmacother 2007; 41: 1734-1739.

115 Tejera A, Santolaria F, Diez ML, Aleman-Valls MR, Gonzalez-Reimers E, MartinezRiera $\mathrm{A}$ et al. Prognosis of community acquired pneumonia (CAP): value of triggering receptor expressed on myeloid cells-1 (TREM-1) and other mediators of the inflammatory response. Cytokine 2007; 38: 117-123.

116 Inoue $Y$, Koizumi A, Wada $Y$, Iso $\mathrm{H}$, Watanabe $\mathrm{Y}$, Date $\mathrm{C}$ et al. Risk and protective factors related to mortality from pneumonia among middle aged and elderly community residents: the JACC Study. J Epidemiol 2007; 17: 194-202.

117 Corrales-Medina VF, Valayam J, Serpa JA, Rueda AM, Musher DM. The obesity paradox in community-acquired bacterial pneumonia. Int $J$ Infect Dis 2011; 15 e54-e57.

118 LaCroix AZ LS, Milles TP, White L. Prospective study of pneumonia hospitalizations and mortality of U.S. older people: the role of chronic conditions, health behaviors, and nutritional status. Public Health Rep 1989; 104: 350-360.

119 Bochicchio GV, Joshi M, Bochicchio K, Tracy K, Scalea TM. A time-dependent analysis of intensive care unit pneumonia in trauma patients. $J$ Trauma 2004; 56: 296-301discussion 301-3.

120 Smith RL, Chong TW, Hedrick TL, Hughes MG, Evans HL, McElearney ST et al. Does body mass index affect infection-related outcomes in the intensive care unit? Surg Infect (Larchmt) 2007; 8: 581-588.

121 El-Solh A, Sikka P, Bozkanat E, Jaafar W, Davies J. Morbid obesity in the medical ICU. Chest 2001; 120: 1989-1997.

122 Arslan E, Atilgan H, Yavasoglu I. The prevalence of Helicobacter pylori in obese subjects. Eur J Intern Med 2009; 20: 695-697.

123 Perdichizzi G, Bottari M, Pallio S, Fera MT, Carbone M, Barresi G. Gastric infection by Helicobacter pylori and antral gastritis in hyperglycemic obese and in diabetic subjects. New Microbiol 1996; 19: 149-154.

124 Renshaw AA, Rabaza JR, Gonzalez AM, Verdeja JC. Helicobacter pylori infection in patients undergoing gastric bypass surgery for morbid obesity. Obes Surg 2001; 11: 281-283.

125 Wu MS, Lee WJ, Wang HH, Huang SP, Lin JT. A case-control study of association of Helicobacter pylori infection with morbid obesity in Taiwan. Arch Intern Med 2005; 165: 1552-1555.

126 Osawa H. Ghrelin and Helicobacter pylori infection. World J Gastroenterol 2008; 14: 6327-6333.

127 Tatsuguchi A, Miyake K, Gudis K, Futagami S, Tsukui T, Wada K et al. Effect of Helicobacter pylori infection on ghrelin expression in human gastric mucosa. Am J Gastroenterol 2004; 99: 2121-2127.

128 Leung CC, Lam TH, Chan WM, Yew WW, Ho KS, Leung G et al. Lower risk of tuberculosis in obesity. Arch Intern Med 2007; 167: 1297-1304.

129 Palmer CE, Jablon S, Edwards PQ. Tuberculosis morbidity of young men in relation to tuberculin sensitivity and body build. Am Rev Tuberc 1957; 76: 517-539.

130 Dooley KE, Chaisson RE. Tuberculosis and diabetes mellitus: convergence of two epidemics. Lancet Infect Dis 2009; 9: 737-746.

131 Kraft R, Herndon DN, Williams FN, Al-Mousawi AM, Finnerty CC, Jeschke MG. The effect of obesity on adverse outcomes and metabolism in pediatric burn patients. Int J Obes (Lond) 2012; 36: 485-490.

132 Huttunen R, Laine J, Lumio J, Vuento R, Syrjänen J. Obesity and smoking are factors associated with poor prognosis in patients with bacteraemia. BMC Infect Dis 2007; 7: 13.

133 Shor-Posner G, Campa A, Zhang G, Persaud N, Miguez-Burbano MJ, Quesada J et al. When obesity is desirable: a longitudinal study of the Miami HIV-1-infected drug abusers (MIDAS) cohort. J Acquir Immune Defic Syndr 2000; 23: 81-88.

134 Jones CY, Hogan JW, Snyder B, Klein RS, Rompalo A, Schuman P et al. Overweight and human immunodeficiency virus (HIV) progression in women: associations HIV disease progression and changes in body mass index in women in the HIV epidemiology research study cohort. Clin Infect Dis 2003; 37(Suppl 2): S69-S80.

135 French AL, Gawel SH, Hershow R, Benning L, Hessol NA, Levine AM et al. Trends in mortality and causes of death among women with HIV in the United States: a 10-year study. J Acquir Immune Defic Syndr 2009; 51: 399-406.

136 Crum-Cianflone NF, Roediger M, Eberly LE, Ganesan A, Weintrob A, Johnson E et al. Impact of weight on immune cell counts among HIV-infected persons. Clin Vaccine Immunol 2011; 18: 940-946.

137 Tedaldi EM, Brooks JT, Weidle PJ, Richardson JT, Baker RK, Buchacz K et al. Increased body mass index does not alter response to initial highly active antiretroviral therapy in HIV-1-infected patients. J Acquir Immune Defic Syndr 2006; 43: 35-41.

138 Hanrahan CF, Golub JE, Mohapi L, Tshabangu N, Modisenyane T, Chaisson RE et al. Body mass index and risk of tuberculosis and death. Aids 2010; 24: 1501-1508.

139 Wanke CA, Silva M, Knox TA, Forrester J, Speigelman D, Gorbach SL. Weight loss and wasting remain common complications in individuals infected with human immunodeficiency virus in the era of highly active antiretroviral therapy. Clin Infect Dis 2000; 31: 803-805.

140 Hodgson LM, Ghattas H, Pritchitt H, Schwenk A, Payne L, Macallan DC. Wasting and obesity in HIV outpatients. Aids 2001; 15: 2341-2342. 